\title{
Foreword: Integrated plant disease management
}

\author{
Michael Jeger • Maria Ivone da Clara • Alan Phillips • Dale Walters • \\ Piet Boonekamp
}

Accepted: 1 February 2012 / Published online: 21 February 2012

(C) KNPV 2012

This volume issue contains the keynote and selected other papers presented at the $9^{\text {th }}$ Conference of the European Foundation for Plant Pathology and the $6^{\text {th }}$ Congress of the Sociedade Portugesa de Fitopatologia held in November 2010 at Évora, Portugal. The papers are focussed on four themes representing the Conference sessions:

\section{- Epidemiology, modelling and management}

M. Jeger $(\bowtie)$

Division of Ecology and Evolution and Centre

for Environmental Policy, Imperial College London,

Silwood Park campus,

Ascot SL5 7PY, UK

e-mail: m.jeger@imperial.ac.uk

M. I. da Clara

Laboratório de Virologia Vegetal,

Instituto de Ciências Agrárias e Ambientais Mediterrânicas,

Universidade de Évora,

Apartado 94,

7002-554 Évora, Portugal

A. Phillips

Centro de Recursos Microbiológicos, Departamento de Ciências da Vida, Faculdade de Ciências e Tecnologia, Universidade Nova da Lisboa,

Caparica 2829-516, Portugal

\section{Walters}

Crop and Soil Systems, Scottish Agricultural College,

King's Buildings, West Mains Road,

Edinburgh EH9 3JG, UK

P. Boonekamp

Plant Research International,

Wageningen UR, PO Box 69, 6700 AB Wageningen,

the Netherlands
- Advances in resistance breeding and biological, chemical and cultural control

- Molecular detection, variability and signalling

- Climate change and disease management

The last theme was also the topic of a major international workshop on Climate Change, held in Évora during the previous week, and papers based on the presentations made have been included. This issue continues the practice of devoting Special Issues of the journal to major themes in Plant Pathology arising from presentations made at major international conferences and workshops.

Integrated disease plant management is based on an integration of knowledge at different scales: from the molecular to the host landscape. Fundamental understanding of the structure of host and pathogen populations, the ability to detect and quantify populations, and the molecular and cellular underpinnings of the host-pathogen interaction provides the basis for advances in control interventions. Advances in resistance breeding and biological, cultural and chemical control in turn provide a sound framework for integrated plant disease management when combined with epidemiological insight and analysis, often obtained through modelling approaches. The prospect of current and future climate change, and the adaptation and mitigation strategies that will be necessary over the coming decades, sets a broader framework for plant disease management as in other aspects of agriculture, horticulture and silviculture. The selected papers included in this Special Issue amply demonstrate the coherence of the chosen themes. 